\title{
Sorus-specific epiphytism affecting the kelps Lessonia nigrescens and L. trabeculata (Phaeophyta)
}

\author{
Enrique Martínez, Juan A. Correa* \\ Departamento de Ecología, Facultad de Ciencias Biológicas, Pontificia Universidad Católica de Chile, Casilla 114-D, \\ Santiago, Chile
}

\begin{abstract}
This study characterizes a tissue-specific association between the green algal epiphyte Sporocladopsis sp. and the sori of its kelp hosts, Lessonia nigrescens Bory and L. trabeculata Villouta et Santelices, occurring on the Pacific coast of Chile. The hypothesis that the distribution pattern of the epiphyte was due to constitutive features of the host was assessed by combined field and laboratory observations. Results showed that the epiphyte was confined to sori of $L$. nigrescens and $L$. trabeculata, failing to invade adjacent vegetative tissues. Infected hosts were found in northern and central Chile, reaching an incidence of $100 \%$ in low intertidal plants of L. nigrescens. Although important modifications in microtopography develop on the surface of the mature sorus of L. nigrescens, colonization by the epiphyte occurs rather early, on immature sori with only minor surface changes. Thus, microtopographical changes per se do not appear as the only explanation for the observed distributional pattern. The absence of periodical renewal of the outer cell wall by the reproductive tissue, in contrast with its continous removal in the vegetative tissue, provides a complementary mechanism that explains the restricted distribution of the epiphyte. In the field, growth, reproduction of the epiphyte, and infection of new tissue of $L$. nigrescens was accomplished in $3 \mathrm{wk}$. In the laboratory, the epiphyte was successfully isolated, and grew to maturity within 1 mo.
\end{abstract}

\section{INTRODUCTION}

Epiphytism of wild and farmed seaweeds by other algae is a common phenomenon. A number of epiphytes (e.g. Enteromorpha spp., Ectocarpus spp., Acrochaetium spp.) appear to have no dependence upon a particular host (Goff 1983) and display a poor degree of host-specificity. On the other hand, there are some highly host-specific epiphytes, such as Polysiphonia lanosa (L.) Tandy growing on Ascophyllum nodosum (L.) Le Jol. (Rawlence \& Taylor 1970), and Microcladia californica Farl. infecting Egregia menziesii (Turn.) Aresch. (González \& Goff 1989). A number of factors, including life span of the host, cuticle peeling, chemical defenses and nutrition have been suggested as potential determinants of such host-specificity (Harlin \& Craigie 1975, Turner \& Evans 1977.

\footnotetext{
- Addressee for correspondence
}

González \& Goff 1989). More direct evidence assessing the role of the above factors is lacking and the phenomenon of host-specificity in algal host-epiphytes associations remains poorly understood.

Kelps are ubiquitous components of temperate ecosystems, and commonly host a wide variety of algal epiphytes (Markham 1969, Loisseaux 1970, Kain 1982, Russell 1983, Whittick 1983). No specific epiphytes have been reported for these hosts, although studies have considered mainly kelps from the northern hemisphere. In central Chile, however, preliminary observations of the intertidal kelp Lessonia nigrescens indicated the presence of a filamentous green epiphyte giving the infected host a velvety appearence. A striking pattern of distribution was noticed, which is characterized by a macroscopically visible infection restricted to the sori of the hosts, suggesting a tissue-specific, rather than a host-specific association. Some morphological characters of the epiphyte, like the presence of a thallus differentiated into a prostrate 
and upright system, and the existence of rudimentary branches, indicate that it belongs to the genus Sporocladopsis Nasr. Fine structure and culture studies are being carried out to elucidate the taxonomic identity of this epiphyte at the species level.

The aim of this study was to characterize the epiphytic infection affecting Lessonia spp. in central Chile, testing the hypothesis that constitutive features of these kelps, mainly changes in microtopography of the tissue, and the dynamics of outer cell wall renewal, were involved in the distribution pattern of the epiphyte on the host.

\section{MATERIALS AND METHODS}

Samples for microscopical analysis were obtained, and quantitative field observations were done, at an intertidal to shallow subtidal kelp bed in Las Cruces $\left(33^{\circ} 30^{\prime} \mathrm{S}, 71^{\circ} 38^{\prime} \mathrm{W}\right)$, central Chile. Qualitative field observations recording the presence of the epiphyte on Lessonia nigrescens were also done in Constitución $\left(35^{\circ} 20^{\prime} \mathrm{S}, 72^{\circ} 25^{\prime} \mathrm{W}\right)$, and Iquique $\left(20^{\circ} 13^{\prime} \mathrm{S}, 70^{\circ} 10^{\prime} \mathrm{W}\right)$ in northern Chile. Field observations recording the presence of the epiphyte also included individuals of the subtidal species $L$. trabeculata from Las Cruces and Iquique.

Topographic characterization of non-infected ironds. The microscopic description of mature and immature reproductive and vegetative frond surfaces was made using scanning electron microscopy (SEM). Pieces of tissue were fixed in a $1 \%$ formaldehyde solution in $0.45 \mu \mathrm{m}$ membrane-filtered seawater, added with $3 \%$ glutaraldehyde. Pieces were changed progressively to distilled water and then dehydrated in an ethanol series before being critical-point dried and gold coated.

Characterization of the infection. Densely and sparcely epiphytized sori and vegetative surrounding tissue were fixed for SEM observations, as above. These materials were also used for light microscopy observations.

Distribution of infected plants in the field. In February 1992, 5 transects, 10 to $11 \mathrm{~m}$ long, were traced along the lower intertidal regions of the Lessonia nigrescens intertidal belt in Las Cruces. All reproductive plants on the transects were observed and the presence of visible epiphytic infection was recorded. A plant was defined as a group of stipes emerging from a common massive holdfast. Epiphytized plants were also surveyed on a higher intertidal site by tracing 2 transects, 8 to $8.5 \mathrm{~m}$ long, and recording the presence of infected fronds.

Dynamics of the infection in the field. To test the role of the frond microtopography on the distribution pattern of the epiphyte, the vegetative surface of 36 tagged fronds was artificially altered using fine-grain sandpaper. Plants were visited after $21 \mathrm{~d}$, and the presence of the epiphyte was recorded. Another group of 6 plants was tagged and photographed to record the macroscopic changes occurring in 3 kinds of reproductive tissues: (1) mature, (2) immature and macroscopically not epiphytized sori, and (3) heavily epiphytized sori ( 2 plants bearing each type of tissue were haphazardly chosen). They were photographed when tagged and at the end of a $26 \mathrm{~d}$ period of permanence in the field.

Isolation of the epiphyte. Mature fronds of Lessonia nigrescens with heavily infected sori were collected in Las Cruces, and within $2 \mathrm{~h}$ taken to the laboratory in a cooler at $4{ }^{\circ} \mathrm{C}$. Infected sori were rinsed gently in running tap water to remove organic debris accumulated among the uprights of the epiphyte. Tissue fragments of $5 \times 5 \mathrm{~mm}$ were obtained from the cleaned sori, and rinsed several times in abundant autoclaved seawater. Additional cleaning of these fragments was accomplished by gentle brushing. Glass needles and a stereo-microscope were then used to dislodge the erect filaments of the epiphyte from the sori. Filaments no larger than 15 cells, but bearing at least 1 sporangium, were transferred to sterile $15 \times 60 \mathrm{~mm}$ glass Petri dishes and screened under an inverted microscope to discard those contaminated with diatoms. Selected filaments of the epiphyte were incubated individually, at $15^{\circ} \mathrm{C}, 40$ to $50 \mu \mathrm{mol} \mathrm{m} \mathrm{m}^{-2} \mathrm{~s}^{-1} \mathrm{PFD}$ and at 16 h light period. Culture medium, an enriched seawater mixture (SFC in Correa 1990), was changed weekly.

Figs. 1 to 7. Lessonia nigrescens free of Sporocladopsis sp. Figs. 1 to 3 . Cross section through the border between the protruding sori and the vegetative tissue. Fig. 1 . High relief sori developed on both sides of the frond. Scale bar $=1 \mathrm{~mm}$. Fig. 2 . Sorus-vegetative tissue border, with reproductive cells resting on the meristoderm. Scale bar $=100 \mu \mathrm{m}$. Fig. 3 . Close-up of sporangia with translucent, swollen apical regions in contact with the surface of the frond. Scale bar $=10 \mu \mathrm{m}$. Figs. 4 to 7 . Surface view of vegetative regions of the frond. Fig. 4 . Smooth outer cell wall, with few irregular cracks interrupting its continuity. Scale bar $=5 \mu \mathrm{m}$. Fig. 5. Part of the outer cell wall has been shed, leaving the subjacent meristodermic cells (MC) exposed. Scale bar $=20 \mu \mathrm{m}$.

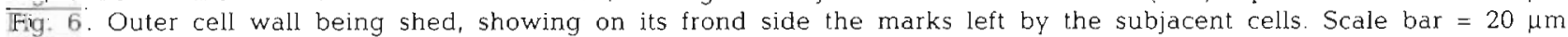
Fig. 7 . Discoid brown epiphytes settled on the outer cell wall. Adhesive filaments are attached to the surface of subjacent meristodermic cells (arrows). Scale bar $=20 \mu \mathrm{m}$ 


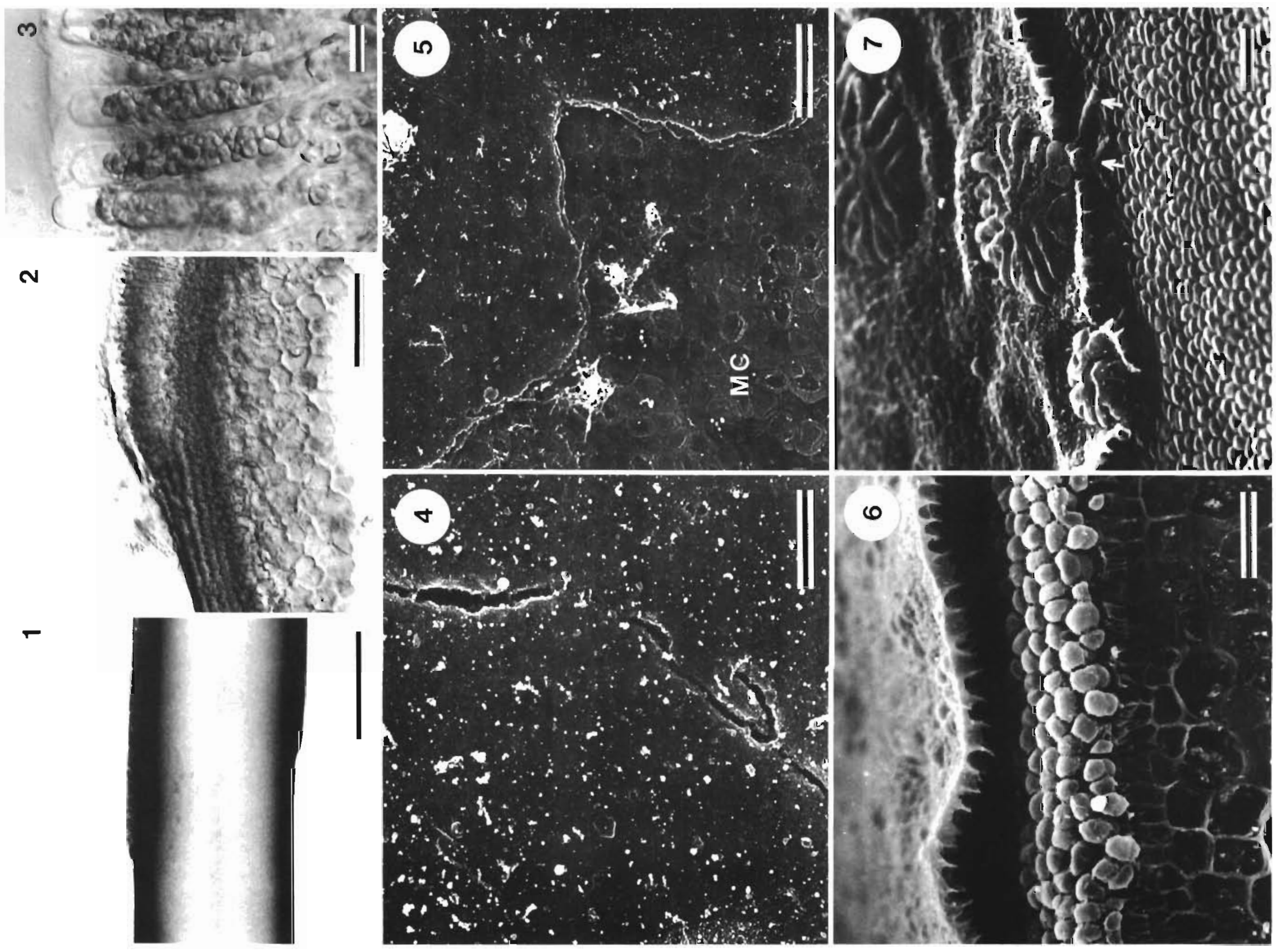




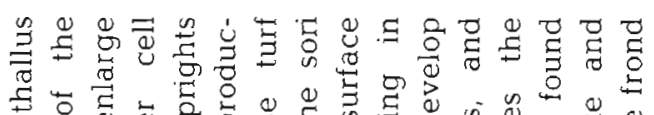

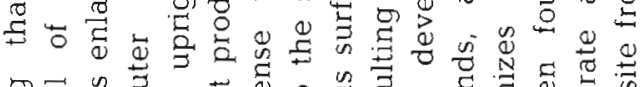

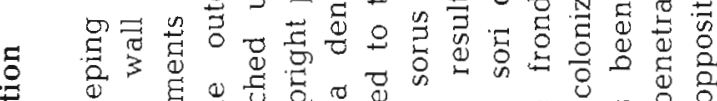

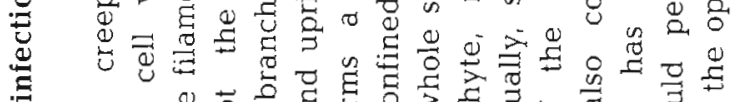

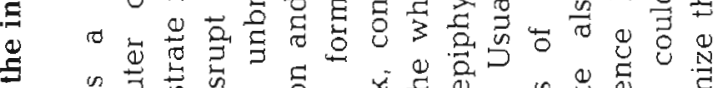

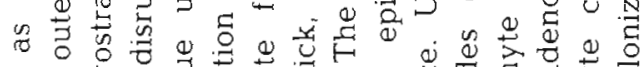

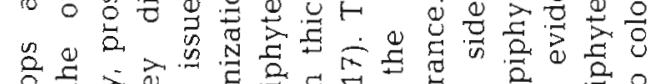

等

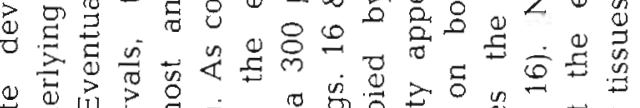

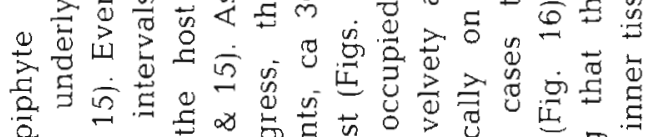

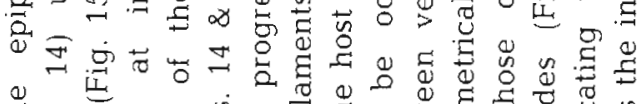

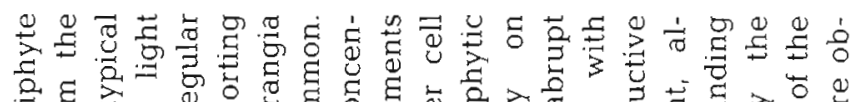

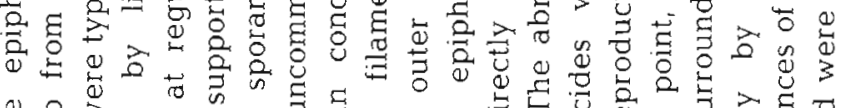

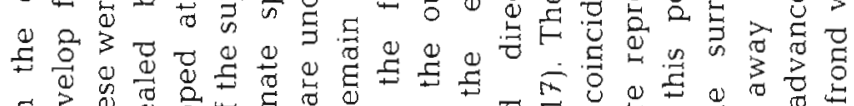

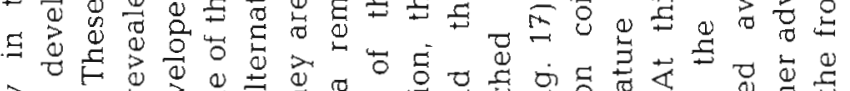

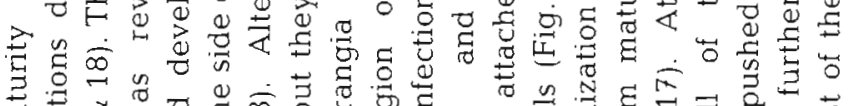

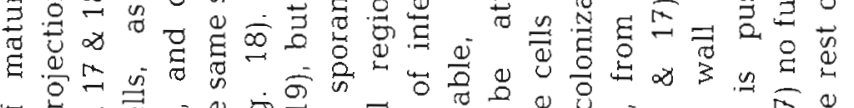

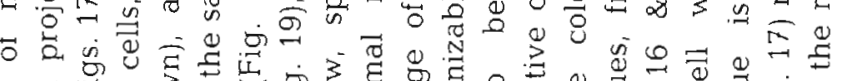

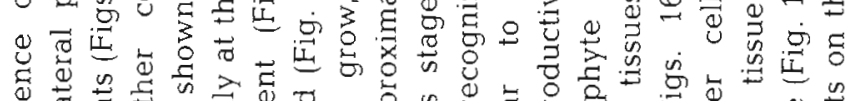

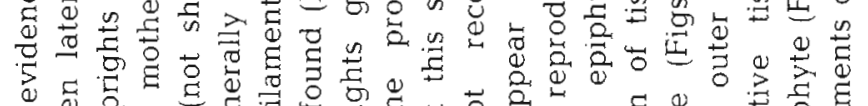

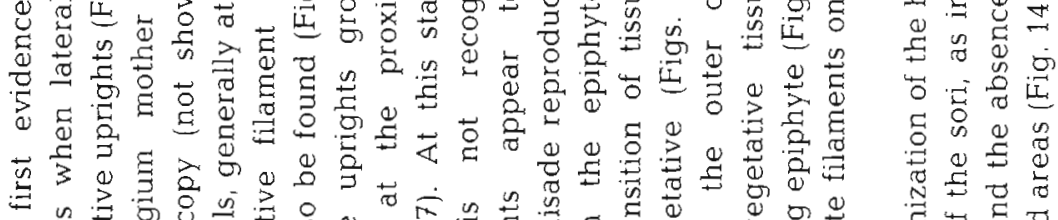
$\begin{array}{lll} & \\ 0 & \end{array}$

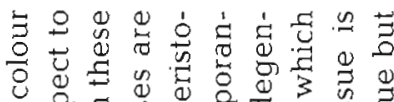

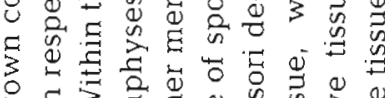

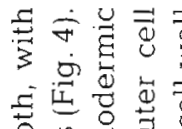

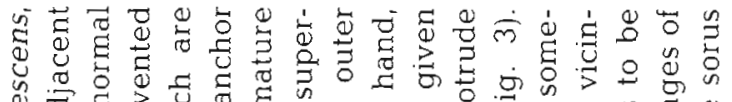

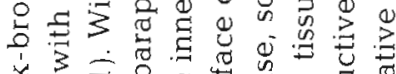

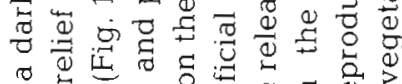

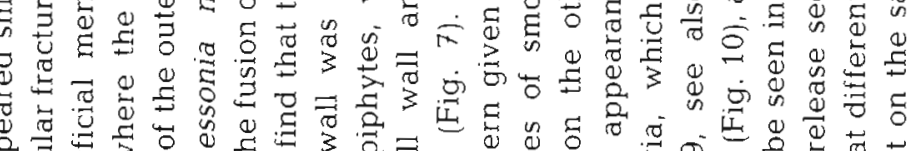

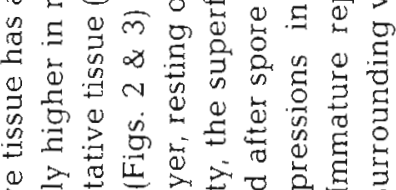

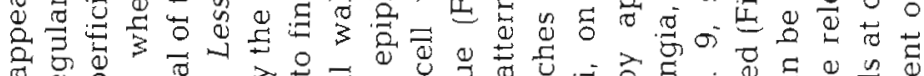

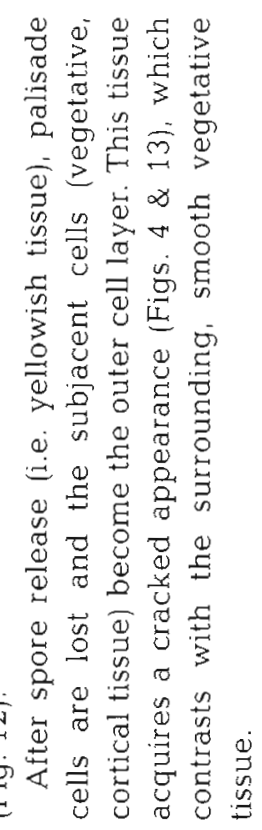

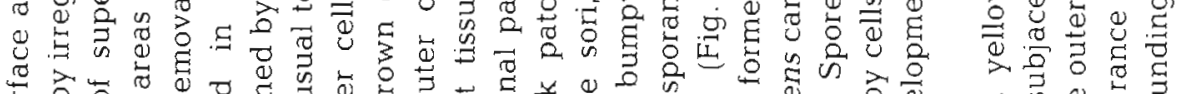

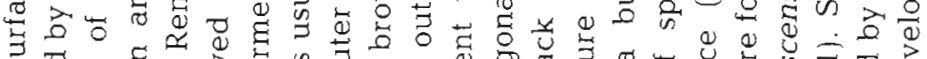

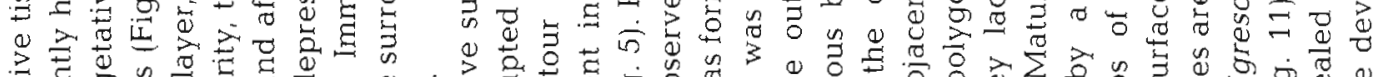

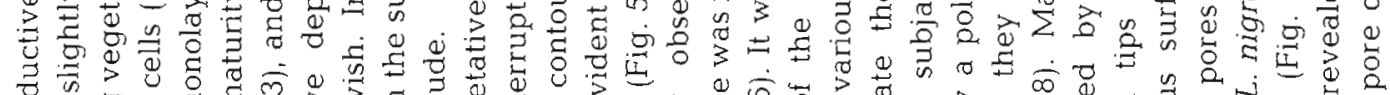

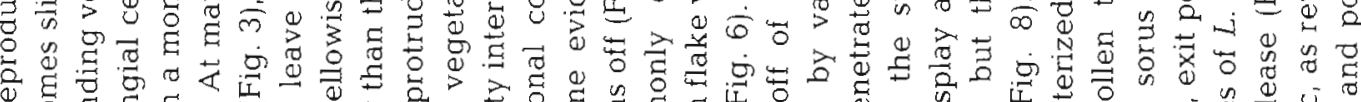

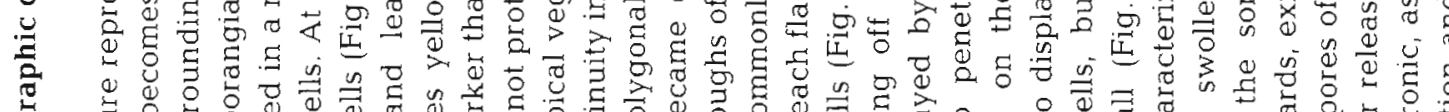

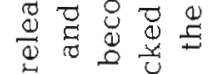

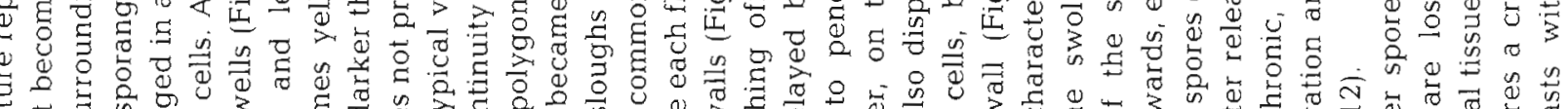

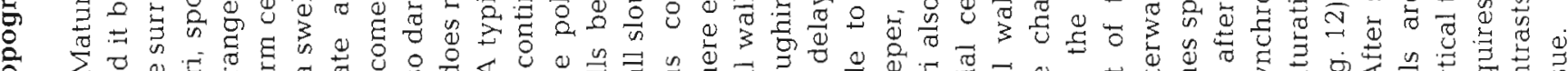

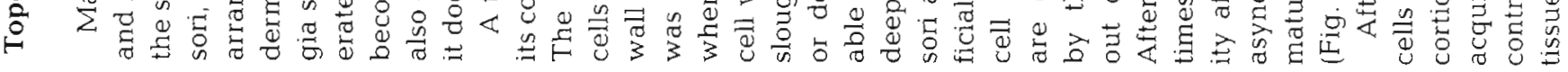

点

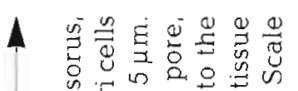

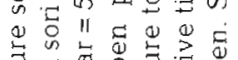

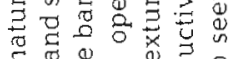

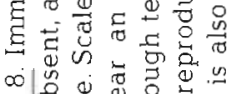

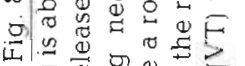

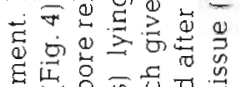

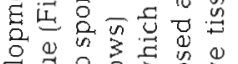

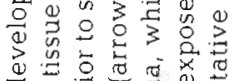

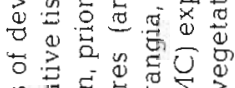

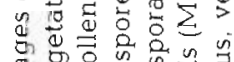

क人

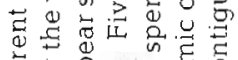

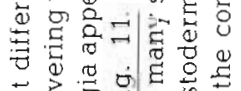

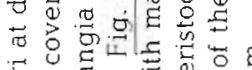

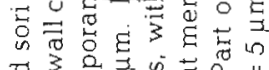

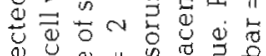

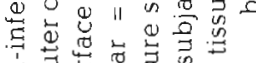

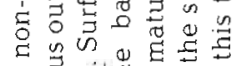

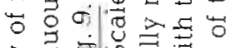

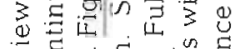

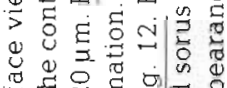

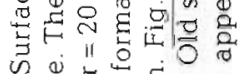

के

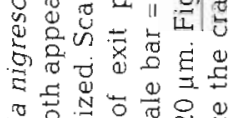

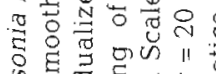

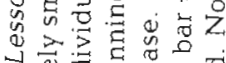

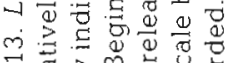

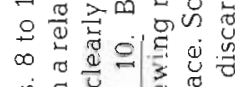

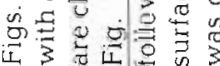




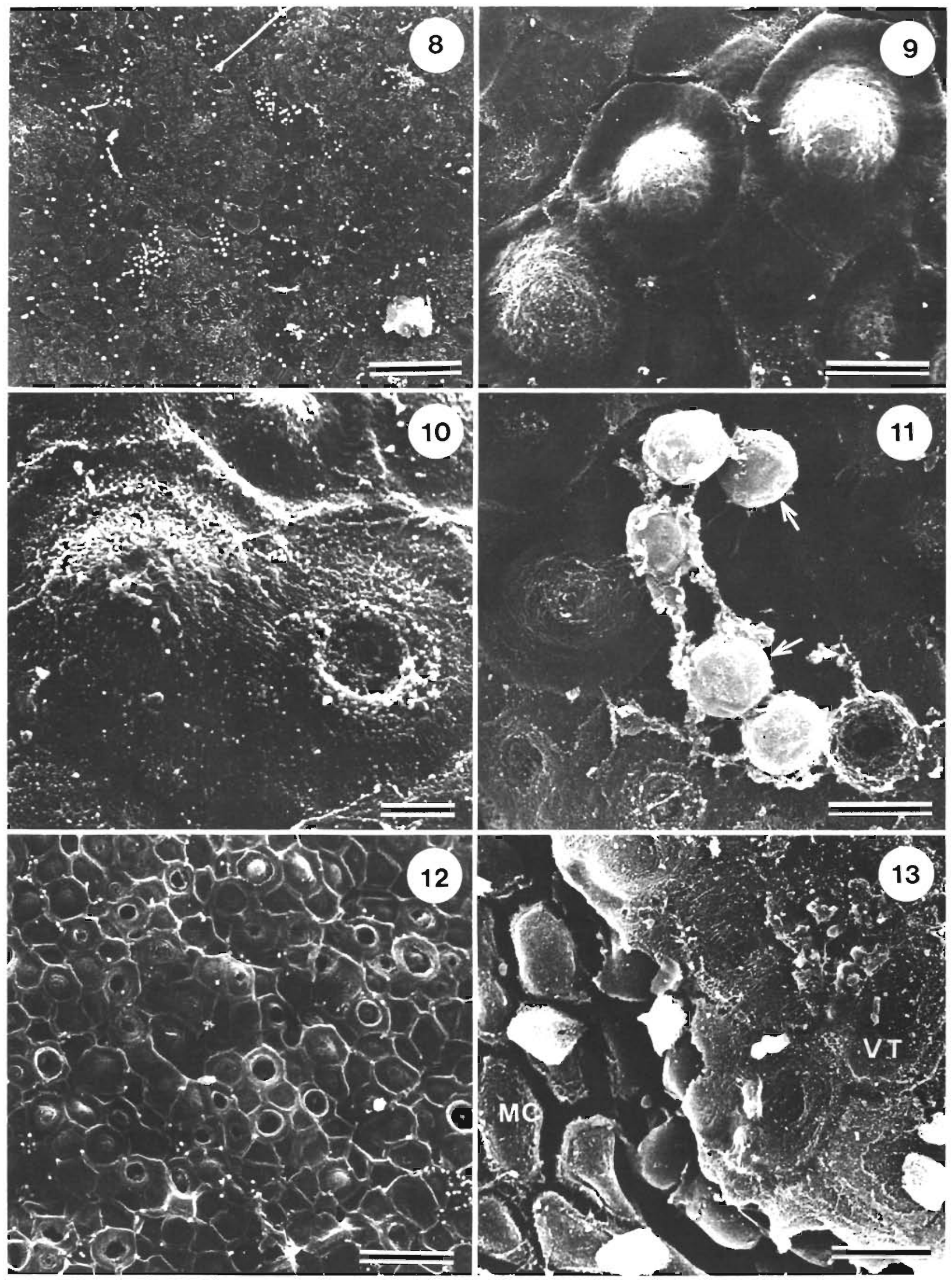




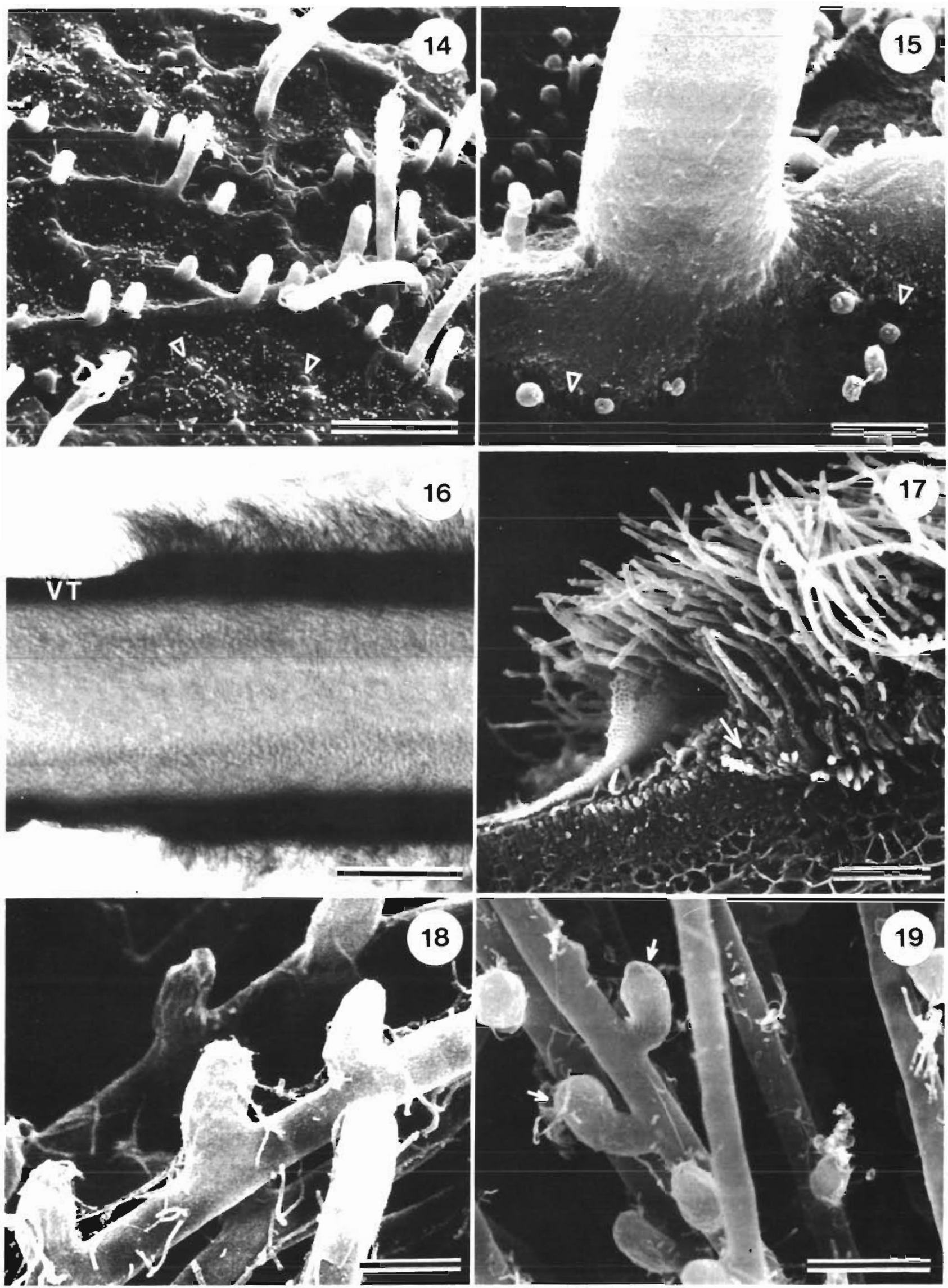




\section{Distribution of infected plants in the field}

The totality of Lessonia nigrescens plants $(n=52)$ from the lower belt limit of distribution in Las Cruces were infected by the epiphyte. In the higher limit, only 6 out of 21 sampled plants were infected. It is important to indicate that all the plants at the lower limit were reproductive, whereas only 8 reproductive plants were found in the higher limit. Thus, $100 \%$ of the reproductive plants in the lower intertidal limit and $75 \%$ of the reproductive plants in the uppermost limit of the belt were infected. All mature sori in each infected plant were heavily epiphytized.

Similar infection to that affecting plants of Las Cruces was observed in plants of Lessonia nigrescens from Constitución and Iquique. Plants of L. trabeculata from Las Cruces and from Iquique also showed heavy infections, and it was always confined to the sori.

While sampling on low and high intertidal zones, no other macroalgae showed infections by the epiphyte affecting Lessonia species.

\section{Dynamics of the infection in the field}

After $26 \mathrm{~d}$ of field exposure, none of the 36 sanded fronds appeared infected, even though the epiphyte was present nearby, on mature sori of the same experimental fronds.

In the other group of 6 tagged plants, the 2 which had sori with heavy infection at the time of tagging lost most of the epiphytes after $21 \mathrm{~d}$, and sori appeared yellowish, characteristic of old reproductive tissue. The 4 remaining plants, which at the beginning of the experiment exhibited mature and immature sori, were heavily infected at the end of the observation period. In all the sori, the epiphytes had reached maturity.

\section{Isolation of the epiphyte}

In culture, sporangia of the mature epiphyte (Fig. 20) released motile spores within 3 to $4 \mathrm{~d}$. Once settled, germination of the spores was unipolar (Fig. 21), resulting in filamentous germlings that initially remained attached to the bottom of the Petri dishes. Subsequent
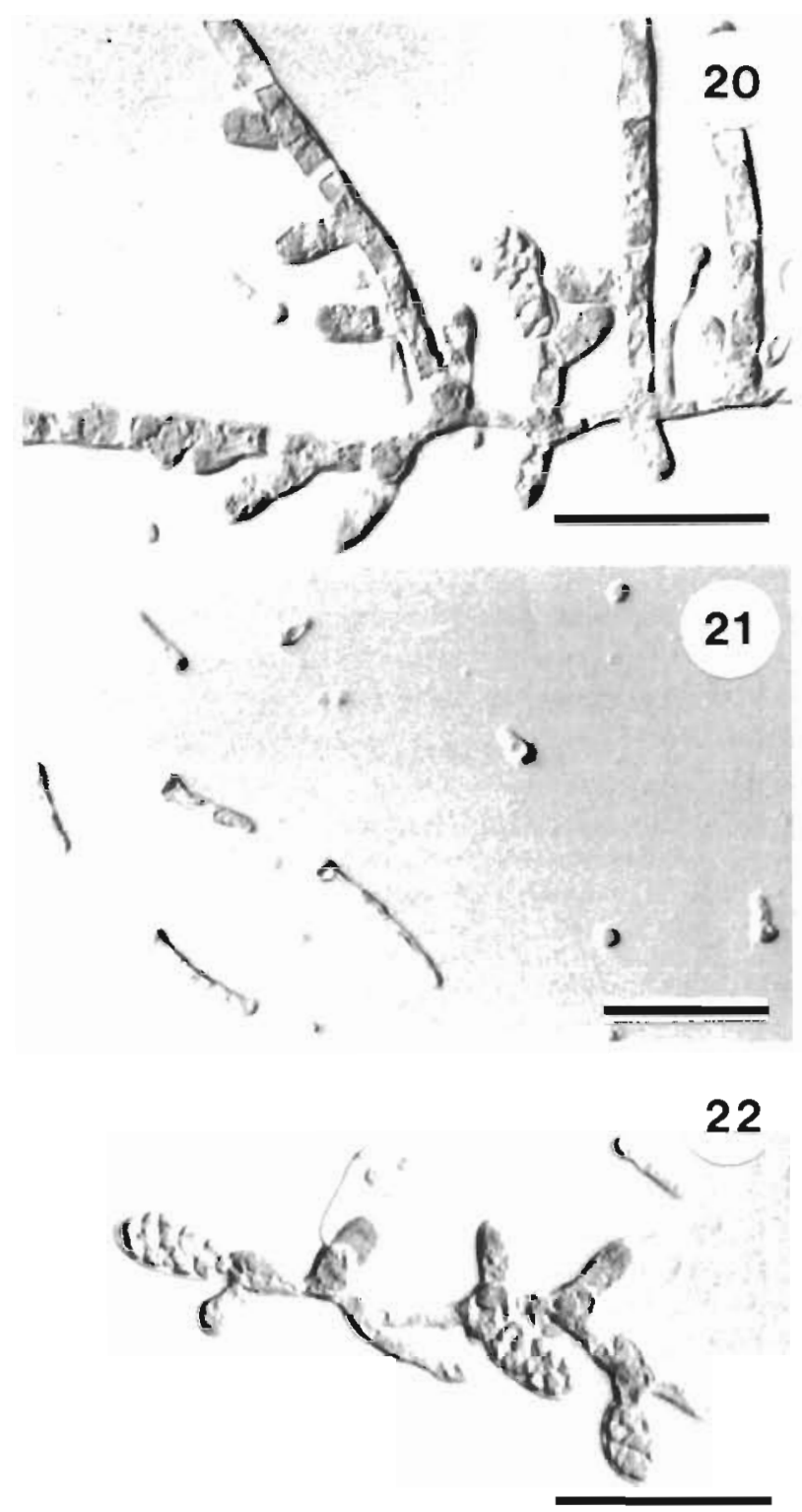

Figs. 20 to 22. Sporocladopsis sp. Isolated cultures of the epiphyte. Scale bars $=50 \mu \mathrm{m}$. Fig. 20. Reproductive uprights, isolated from infected Lessonia nigrescens sori. Fig. 21. Settled spores and germlings at different stages of development.

Fig. 22. Mature sporangia in plant developed from spores

development of germlings consisted in the production of uniseriate erect filaments, from where short

Figs. 14 to 19. Lessonia nigrescens sori infected by Sporocladopsis sp. Fig. 14. Early stage of the infection, with the prostrate thallus of the epiphyte attached to immature, swollen, reproductive cells (arrowheads). Sparse upright filaments are issued from prostrate thallus. Scale bar $=50 \mu \mathrm{m}$. Fig. 15. Close-up of a site where an upright filament is issued. The host surface appears disrupted by the development of the prostrate filament (arrowheads). Scale bar $=3 \mu \mathrm{m}$. Figs. 16 to 19 . Fully developed infection. Fig. 16. Opposite, infected sori. Epiphytic filaments do not colonize the adjacent vegetative tissue (VT). Bar= 500 $\mu \mathrm{m}$. Fig. 17. Border between the infected sorus and the adjacent vegetative tissue. Disposable outer cell wall is lifted away, but advancing prostrate filaments do not trespass the border (arrow). Scale bar $=100 \mu \mathrm{m}$. Figs. 18 to 19. Upright filaments becoming mature, before the spent subjacent sorus of the host is discarded. Fig. 18. Unilateral issuing of sporangia, Scale bar $=10 \mu \mathrm{m}$. Fig 19. Bilateral sporangia (arrows). Scale bar $=20 \mu \mathrm{m}$ 
branches were issued (Fig. 22). These branches did not develop further as vegetative filaments, but instead the terminal cell became a sporangium, bearing 8 to 16 spores. Reproduction was quite active, and usually in $1 \mathrm{mo}$, the progeny of a single isolated filament covered most of the Petri dish bottom.

\section{DISCUSSION}

The data gathered in this study suggest a highly specific tissue-epiphyte association between the kelp Lessonia nigrescens and Sporocladopsis sp. The restricted presence of an epiphyte could result from the abiotic conditions imposed by the particular habitat of the host (i.e. intertidal, in the case of $L$. nigrescens). A similar hypothesis has been suggested (Norton et al. 1977, Kendrick et al. 1988) and experimentally demonstrated (Mârkham 1969, Harin 1973) ds the cause of host-specificity in different associations involving algal epiphytes. However, infections by the same epiphyte on the subtidal species Lessonia trabeculata, that were identical to those affecting $L$. nigrescens, make unsustainable the hypothesis that tissue-specificity in the studied association is mediated by the abiotic conditions prevailing in the lower intertidal. As expected, the subtidal habitat provides a quite different array of biotic and abiotic conditions for the epiphyte.

In contrast with an abiotically-driven specificity, some host features appear to play much more important roles in determining the pattern of specificity displayed by the green epiphyte. For example, our results clearly indicate that the micro-texture of the Lessonia spp. frond changes from a smooth surface in vegetative areas, to a rougher, uneven surface in the sori. By becoming rougher, it is expected that the surface of the host turns into a more suitable substratum for settling spores, a response similar to that observed on artificial substrata by Harlin \& Lindberg (1977). However, SEM and field observations show that colonization by Sporocladopsis sp. takes place during early soral development, when differences in texture with the vegetative tissue are minimal. Thus, changes in texture alone seem to be insufficient to explain the selective infection of Lessonia spp. sori

An apparently stronger influence seems to be exerted by the dynamics of the outer cell wall of the host. The 2 species of Lessonia considered in the present study shed their outer cell wall intermittently, which is subsequently replaced by a new protective layer. However, as shedding affects only the vegetative tissue, it is at this place where epiphyte sporelings could be eliminated before developing into a creeping thallus. In the case of sori, the outer cell wall is not replaced, and therefore turns into a more stable substra- tum, likely to become more susceptible to colonization by epiphytes. Shedding of the outer cell wall also occurs in other brown (Filion-Myklebust \& Norton 1981 , Moss 1982), green (McArthur \& Moss 1977), and red seaweeds (Sieburth \& Tootle 1981, Craigie et al. 1992). This process has been considered a self-cleaning mechanism (sensu Filion-Myklebust \& Norton 1981), and its occurrence on the vegetative, and not on the fertile, tissues of Lessonia spp. could certainly explain the selective presence of epiphytes on the sori of these hosts. This has been demonstrated in Elachista scutulata (Sm.) Aresch and Herponema velutinum (Grev.) J. Ag., both epiphytes specific to the receptacles of Himanthalia elongata (L.) Gray (Russell \& Veltkamp 1984). In Ascophyllum nodosum, natural or induced discontinuities in the thallus surface prevent the process of self-cleaning that occurs during the skinshedding of this alga. These discontinuities have been suggested to be responsible for the specificity in host colonization by the epiphyte Polysiphonia lanosa (Pearson \& Evans 1990).

Although the above arguments may well explain the restricted presence of the described epiphyte on Lessonia spp. sori, they fail to explain why it is always that particular epiphyte, the one found on the sori. Sporocladopsis sp. is an extremely fast-growing organism able to develop heavy infections in about 3 wk, as indicated by our tagged, epiphyte-free plants. In laboratory cultures, Petri dish bottom areas of $20 \mathrm{~cm}^{2}$ were completely colonized within 1 mo following an inoculation with a single filament of the epiphyte, 8 to 15 cells in size. It is expected then that any other epiphyte reaching the surface of the sori could be outgrown by this epiphyte. In fact, other epiphytes were often seen on the vegetative tissue surrounding the infected sori (see Fig. 7).

The possible occurrence of recognition events between the host and the epiphyte, resulting in a compatible interaction, is an alternative explanation for the tissue specificity. It is known that some green endophytes only infect the lambda-carrageenan producer. sporophytic phase of the red alga Chondrus crispus Stackh. (Correa \& McLachlan 1991). Also, the chemical composition of the cell wall associated with reproductive tissues, or cells, differs from that of vegetative regions of the thallus (Young 1980, Cole et al. 1985, 1986 , Pfister 1992). The occurrence of such a phenomenon in Lessonia spp. could provide the molecular basis for the differential susceptibility to epiphytism shown by reproductive and vegetative tissues of these hosts. In this context, our microscopic observations showing that the colonization of the host ceases abruptly at the border between the reproductive and vegetative tissues suggest the accurrence of recognition events, but we lack experimental evidence to support it. 
The described epiphyte infecting Lessonia spp. appears hichly coupled to the reproductive behaviour of its host. Mature fronds in L. nigrescens occur throughout the year, but sori are more frequent from July to August (Santelices \& Ojeda 1984). The process of differentiation of vegetative tissue into a fully mature sorus takes place within a 1 to 2 mo period, after which the sorus degenerates and is eliminated from the frond (Martínez pers. obs.). Therefore, that is the time available for the epiphyte to settle, develop, and become mature. Reaching maturity in 10 to $15 \mathrm{~d}$ in the laboratory and less than $21 \mathrm{~d}$ in the field clearly demonstrates the ability of the epiphyte to fit successfully within the reproductive time frame of Lessonia spp. Life histories of other epiphytes, as in the case of some ectocarpoids, are known to be highly coordinated with the life histories of their algal hosts, helping to explain the observed high host-specificity (Russell 1983, 1988). Similarly, it was demonstrated that the highly host-specific, rhodophycean epiphyte, Porphyra nereocystis Anderson regulates the production of conchospores in response to dual short day-long day conditions for about 3 to $4 \mathrm{wk}$. This strategy was interpreted as an adaptation to coordinate the presence of infecting propagules with the seasonal availability of the host, Nereocystis luetkeana (Mertens) Postels et Ruprecht, and to overcome competition with other potential epiphytes (Dickson \& Waaland 1985).

The studied organism is not an obligate epiphyte. Although in the wild the epiphyte only develops on mature sori of Lessonia spp., it was successfully isolated from its hosts, and reproduction by spores has proceeded normally since. At first glance, the association between Sporocladopsis and its host Lessonia spp., could be categorized as a comensalistic symbiosis (Ahmadjian \& Paracer 1986). Although preliminary laboratory experiments suggest some deleterious effects of the infection, particularly during release of spores by $L$. nigrescens, in the field the infection does not seem to have any obvious detrimental effect on Lessonia spp.

Acknowledgements. We thank critical reading and comments to improve an early version of this manuscript by $\operatorname{Dr} B$. Santelices. We also thank suggestions by 3 anonymous reviewers and by Dr R. Nielsen on the genus Sporocladopsis. Laboratory assistance by V. Flores and P. Sánchez, and funding provided by FONDECYT grants 612-91 to E.M. and 75191 to J.C. are deeply appreciated.

\section{LITERATURE CITED}

Ahmadjian, V., Paracer, S. (1986). Symbiosis. An introduction to biological associations. University Press of New England, Hanover
Cole, K., Carol, C. M., Reid, P. E., Sheath, R. G. (1985). Comparative studies on the cell walls of sexual and asexual Bangia atropurpurea (Rhodophyta). I. Histochemistry of polysaccharides. J. Phycol. 21: 585-592

Cole, K. M., Park, C. M., Reid, P. E. (1986). Comparative studies on the cell walls of sexual and asexual Bangia atropurpurea (Rhodophyta). Il. Electrophoretic patterns of polysaccharides. J. Phycol. 22: 406-409

Correa, J. A. (1990). Pigmented algal endophytes of Chondrus crispus Stackhouse: host specificity, fine structure, and effects on host performance in infections by Acrochaete operculata Correa \& Nielsen and $A$. heteroclada Correa \& Nielsen. Ph.D. thesis, Dalhousie Univ.

Correa, J. A., McLachlan, J. L. (1991). Endophytic algae of Chondrus crispus (Rhodophyta). III. Host specificity. J. Phycol. 27: 448-459

Craigie, J. S., Correa, J. A., Gordon, M. E. (1992). Cuticles from Chondrus crispus (Rhodophyta). J. Phycol. 28: $777-786$

Dickson, L. G., Waaland, J. R. (1985). Porphyra nereocystis: a dual-daylength seaweed. Planta 165: 548-553

Filion-Myklebust, C., Norton, T A. (1981). Epidermis shedding in the brown seaweed Ascophyllum nodosum (L.) Le Jolis, and its ecological significance. Mar. Biol. Lett. 2: $45-51$

Goff, L. J. (1983). Marine algal interactions: epibiosis, endobiosis, parasitism and disease. In: Tseng, C. K. (ed.) Proceedings of the Joint China-U.S. Phycology Symposium. Science Press, Beijing, p. 221-274

González, M. A., Goff, L. J. (1989). The red algal epiphytes Microcladia coultieri and $M$. californica (Rhodophyceae, Ceramiaceae). II. Basiphyte specificity. J Phycol. 25: 558-567

Harlin, M. M. (1973). (Obligate) algal epiphyte Smithora naiadum grows on a synthetic substrate. J. Phycol. 9: $230-232$

Harlin, M. M., Craigie, J. S. (1975). The distribution of photosynthate in Ascophyllum nodosum as it relates to epiphytic Polysiphonia lanosa. J. Phycol. 11: 109-113

Harlin, M. M., Lindbergh, J. M. (1977). Selection of substrata by seaweeds: optimal surface relief. Mar. Biol. 40: 33-40

Kain, J. M. (1982). The reproductive phenology of nine species of Rhodophyta in the subtidal region of the Isle of Man. Br. phycol. J. 17: 321-331

Kendrick, G. A., Walker, D. I., McComb, A. J. (1988). Changes in distribution of macro-algal epiphytes on stems of the seagrass Amphibolis antartica along a salinity gradient in Shark bay, Western Australia. Phycologia 27: 201-208

Loisseaux, S. (1970). Notes on several Myrionemataceae from California using culture studies. J. Phycol. 6: 248-246

Markham, J. W. (1969). Vertical distribution of epiphytes on the stipe of Nereocystis luetkeana (Mertens) Postels et Ruprecht. Syesis 2: 227-240

McArthur, D. M., Moss, B. L. (1977). The ultrastructure of cell walls in Enteromorpha intestinalis (L.) Link. Br. phycol. J. 12: $359-368$

Moss, B. L. (1982). The control of epiphytes by Halidrys siliquosa (L.) Lyng. (Phaeophyta, Cystoceiraceae). Phycologia 21: 1185-1191

Norton, T. A., Hiscock, K., Kitching, J. A. (1977). The ecology of Lough Ine. XX. The Laminaria forest at Carrigathorna. J. Ecol. 65: 919-941

Pearson, G. A., Evans, L. V. (1990). Settlement and survival of Polysiphonia lanosa (Ceramiales) spores on Ascophyllum nodosum and Fucus vesiculosus (Fucales). J. Phycol. 26: $597-603$

Pfister, C. A. (1992). Costs of reproduction in an intertidal 
kelp: patterns of allocation and life history consequences. Ecology 73: 1586-1596

Rawlence, D. J., Taylor, A. R. A. (1970). The rhizoids of Polysiphonia lanosa. Can. J. Bot. 48: 607-611

Russell, G. (1983). Formation of an ectocarpoid epiflora on blades of Laminaria digitata. Mar. Ecol. Prog. Ser. 11: $181-187$

Russell, G. (1988). Distribution and development of some Manx epiphyte populations. Helgoländer Meeresunters. 42: $477-492$

Russell, G., Veltkamp, C. J. (1984). Epiphyte survival on skin-shedding macrophytes. Mar. Ecol. Prog. Ser. 18: $149-153$

Santelices, B., Ojeda, P. (1984). Recruitment, growth and survival of Lessonia nigrescens (Phaeophyta) at various tidal

This article was submitted to the editor levels in exposed habitats of central Chile. Mar. Ecol. Prog. Ser. 19.73-82

Sieburth, J. M., Tootle, J. L. (1981). Seasonality of microbial fouling on Ascophyllum nodosum (L.) Le Jol., Fucus vesiculosus L., Polysiphonia lanosa (L.) Tandy and Chondrus crispuss Stack. J. Phycol. 17: 57-64

Turner, C. H. C., Evans, L. V. (1977). Physiological studies on the relationship between Ascophyllum nodosum and Polysiphonia lanosa. New Phytol. 79: 363-371

Whittick, A. (1983). Spatial and temporal distributions of dominant epiphytes on the stipes of Laminaria hyperborea (Gunn.) Fosl. (Phaeophyta:Laminariales) in S. E. Scotland. J. exp. mar. Biol. Ecol. 73:1-10

Young, D. N. (1980). Unusual cell wall ultrastructure in Antithamnion (Rhodophyta). Br. phycol. J. 15: 119-124

Manuscript first received: November 30, 1992 Revised version accepted: February 17, 1993 